\title{
Government Responsiveness in the Prevention of Spreading Covid-19: Vietnam and Indonesia in Comparison
}

\author{
M. Yusuf ${ }^{1}$, Ady Muzwardi ${ }^{2}$, Muhammad Syukri $^{3}$ \\ ${ }^{1}$ Department of Government Studies, Universitas Jambi, Indonesia (email: myusuf@unja.ac.id) \\ ${ }^{2}$ Department of International Relation, Universitas Maritim Raja Ali Haji, Indonesia \\ (email: ady_muzwardi@umrah.ac.id) \\ ${ }^{3}$ Department of Public Health, Universitas Jambi, Indonesia (email: syukri.muhammad@unja.ac.id)
}

\begin{abstract}
This study attempts to reveal the responsiveness of both Vietnam and Indonesia in anticipating the massive external shock that was Coronavirus-19. A change in external factors, such as pandemics, has challenged politicians and governments at large to be responsive in resolving problems quickly. Generally, recent research focused on reactive policies, disaster mitigation, and medical issues, while discussing government responsiveness in disease prevention is only covered in a few studies. This research uses a comparative qualitative method with an analysis period from December 2019 to the end of May 2020. The data is derived from various secondary information sources, such as research results, news, official reports, or government statements, which are interpreted through a systematic coding process to explain the phenomenon. The primary results showed that government responsiveness determines the success of handling the deadly coronavirus in pre-pandemic and current pandemic situations. A strong political will and leadership style is essential, and a solid bureaucratic apparatus in implementing policies and programs is decisive. As an authoritarian democracy, in collaboration with CDC, Vietnam was able to anticipate before the pandemic spread and succeeded in suppressing the spread after it was detected even though it had issued a blundering policy. Meanwhile, as a democratic country, Indonesia slowly responded to the outbreak by decision making where the pandemic is handled after it is detected and spread to various regions. The rulers tend to avoid the experts and growing opinions addressed to the government.
\end{abstract}

\section{Keywords:}

covid-19; prevention; responsiveness

\section{Introduction}

This paper aims to analyse the government's responsiveness in preventing the Coronavirus disease 2019 (Covid-19) spreading in two developing countries, Vietnam and Indonesia, which have relatively weak health systems. Responsiveness in health-crisis management is an essential aspect in the health sector because a fast response contributes to satisfaction, well-being, and dignity (Ali et al., 2015; Valentine et al., 2015). External changes from the current health sector impacting the global and national economy requires the bureaucracy to adjust the work rhythm to overcome the health problem.

Although the outbreak spreading is quickly occurring because of a combination of population growth and rapid transportation system, the infectious disease can be controlled quickly. In recent years, scientists had looked after some contagious diseases, such as SARS in 2002/2003, Avian Influenza in 2005, Swine Influenza in 2009/2010 and Ebola in 2014. It was not long until scientists found their vaccines, antibiotics, and health sciences that supported technological development. 
Finally, the epidemic's impact had dropped dramatically compared to outbreaks such as Yersinia Pestis, Smallpox and Spanish Flu (Harari, 2018).

The sophisticated technology and health science contribute to the strength of the health system, but the challenges in the healthiness sector continuously increase. It can be seen that the new fact is coming since the Covid-19 outbreak has spread globally, with 6,064,778 confirmed cases and 369,254 deaths by Mei 31, 2020 (JHU, 2020). The cases have been increasing while the possibility of several epicentres will emerge in developing countries. In countries without comprehensive medical supervision, it can increase local and global virus outbreaks. Although there are already restrictions on air traffic, shipments, or other transportation, this virus is still difficult to be controlled because the virus spreading rate is very high and structural stability on the surface (Lau et al., 2020).

After the virus was first detected in Wuhan, Covid-19 spread quickly to various countries. Southeast Asia is part of the Covid-19 spreading; the first case was confirmed on January 13 in Thailand and Vietnam, which borders China; the first case has been confirmed since on January 23, 2020, along with Singapore, as of May 31, a total of 327 patients, no death reported. Meanwhile, in Indonesia, the first cases were identified on March 02, 2020 (La et al., 2020; WHO, 2020), no data explained when this virus began to spread so far. Vietnam has succeeded in flattening the curve of transmission rate, while Indonesia experienced increasing cases until May 312020 (figure 1). How and why Vietnam can decrease the spread of the virus. On the contrary, Indonesia is facing a significant threat to health, and how is the government responsiveness facing threats in both countries. This paper addresses the question: How is the governments' responsiveness of the two countries in tackling the pandemic?. In answering the question, this paper discusses responsiveness through prepandemic response and pandemic, including government response, political will, leadership style, bureaucratic government, and priority programs.

\section{Literature Review}

The study about the handling of pandemic spreading is addressed to the effectiveness of the implementation of quarantine. This study shows that by reducing individual contact, interventions such as quarantine and isolation could effectively reduce the potential number of COVID-19 infections and delay peak infection times (Hou et al., 2019). Other studies describe epidemiological characteristics and highlight the effects of lockdowns and nonpharmaceutical interventions such as extended holidays, travel restrictions, hospitalisation, and quarantine. The prevention of the transmission of the virus through lockdown policies has shown results that can limit the spread (Ji et al., 2020; Lin et al., 2020).

An analysis of China's failure in an early warning for the COVID-19 outbreak shows that a governance system dominated by structural forces and overriding communities has devastating consequences. The scientific community plays a crucial role in dealing with the various challenges of epidemic outbreaks ( $\mathrm{Gu} \& \mathrm{Li}, 2020)$. The study assessing the challenges of governance and policymaking in a pandemic case reveals that policy actors consider risk communication, international public policy dynamics and territorial governance as significant management challenges in managing epidemics at the macro level. Other results identified that although contingency management for epidemiological problems requires both technical and scientific considerations to be addressed in governance settings, there is also a major "wicked problem" in the context of the public policy covering the health security sector (Connolly, 2015).

Meanwhile, the most recent study on 
pandemic response in Indonesia provides detailed reporting and analysis of the current rapid response to Covid-19 between January and March 2020. In particular, the researchers highlight the government's responses, nongovernmental organisations, and the public. Efforts to prevent the spread of a pandemic are to respond to the Covid-19 through early detection, human surveillance, environmental surveillance, an inspection of transportation means, and the inspection of goods (Djalante et al., 2020; Sukmana et al., 2020). Most of these studies review clinical actions combined with non-clinical activities and their effects. Nevertheless, these have limited review of government responsiveness in preventing the virus from spreading. The main point is preventive action from an institutional perspective that emphasises the government's responsiveness to the external demands addressed to public bodies. The governments' responsiveness is an exciting object of study, particularly how they anticipate and reduce the spread of Covid-19. The main idea of this paper comes from the assumption that government responsiveness is vital in epidemiology management.

The changes from the external factor contribute to emphasise government institutions in providing public services. The government meets the challenges in increasing demographic, economic growth, and also improving public service. The failure of these challenges can risk many lives eventually. The public sector must overcome the crisis and be completed efficiently with good service without spending much of the budget. Flexibility and responsiveness are needed to make it last, so the traditional structures depending on regulations and administration decrease (Gonzi, 2019). Environmental and organisational factors determine public responsiveness; external democratic control helps set the direction of bureaucratic policy and regulates the suitability of external stakeholders and bureaucrats regarding priority issues and values. Management systems influence the policies or priorities that result, but more importantly, they affect the ability of the organisation to respond to policies or priorities. External controls and internal management must be integrated to explain the level of public response (Yang \& Pandey, 2007).

The study of responsiveness in the new public service (NPS) perspective is considered another object that does not abolish but complements old public administration (OPA) criteria. It focuses on internal aspects of the organisation, response to clients and constituents, and new public management (NPM) that emphasises efficiency, which concentrates on consumer response (Denhardt \& Denhardt, 2015). Responsiveness emphasises aspects where the government must provide the services or products that the majority of citizens want. Due to products or services bought with tax revenue, the government is responsible for satisfying customers, operating cost-effectively, and providing services that citizens have asked for (Cope, 1997).

Legitimate officials and bureaucracy serve as neutral instruments used to meet public demands. Elected officials represent the public interest, while the bureaucracy responds to the public through complete obedience to elected officials' interpretation of the public demand. Bureaucracies require responses to public demand represented by public officials. Bureaucratic representatives emphasise the responsibility of bureaucracy to represent the state in interaction with the public. Administrative institutions are created for specific purposes, and their primary responsibility is to provide proper administration, which can be defined in various ways (Saltzstein, 1992).

In this context, the government's response to people's preferences represents government democracy. The democratic government must focus on responding to the public interest and can 
satisfy citizen demand. There is no consensus on the operationalisation of appropriate responses, attracting various forms of responsiveness, preferred responsive objectives, or the best way to achieve responsively (Yang \& Pandey, 2007). Responsiveness is an aggregate indicator that can be described into several dimensions: responsiveness that is addressed to elected officials, limited solitude to rules/norms/ procedures, responsive to administrators' specified goals, entrepreneurial responses to an individual, collaborative responsiveness to stakeholder consensus, and negotiating responsive to conflicting demands (Bryer, 2007).

\section{Methods}

This study uses comparative qualitative research methods to understand the responsiveness of pandemic prevention in Vietnam and Indonesia, with an analysis period from December 2019 to the end of May 2020. This period is the main unit of analysis because it enters into a critical early period of responsiveness in preventing the disease, specifically the term of mitigation, preparedness, and response. The use of this method is based on the belief that a qualitative approach can find or understand various facts (Sugiyono, 2014). Sometimes various phenomena are challenging to comprehend satisfactorily; with this method, the author can provide a profound and convincing description of various irregular data. Brief research on the comparison of the two countries was conducted to consider having similar and regional characteristics in the same category as developing countries. Information finding began after the confirmation of the Covid-19 case in China. Various relevant cases about research issues in the two countries were used as references. This method may have weaknesses because each of the two countries has its cases. However, by using the same variable, various cases can be observed.
This paper relies on information from various secondary sources, such as research results, reports, news, government speeches and reports, rules, social media platforms, websites, and other relevant or related sources until May 31, 2020, to cover existing social phenomena. Information finding was conducted carefully, according to the theme of the writing and the theoretical framework used. All data is selected based on relevance and then confirmed repeatedly. This information will help provide a better understanding of how countries plan and respond to this pandemic and in the future. These various data points are analysed using systematic coding (open coding, axial coding and selective coding) to find concepts and categories and prove the initial hypothesis (Corbin \& Strauss, 2015; Leedy \& Ormrod, 2016). This step was conducted to show the facts as a cohesive unit of qualitative data, an analysis, and techniques to collect and interpret conclusions from the study of the data obtained.

\section{Results \\ Pre-Pandemic and Initial Stage}

Before the first cases were confirmed in Vietnam, the government responded by conducting a threat assessment, along with the improvement of guidelines and plans as a measure to prevent the spread of newly detected diseases. Since the beginning of the outbreak, the Vietnamese government has focused on hospital management policies to ensure the readiness of the medical system to cope with the pandemic. The government has issued several directives regarding hospital management since the end of January 2020; for example, how to screen patients during hospital visits or the division of special responsibilities at each level of the hospital (La et al., 2020).

When the news of Covid-19 spread, the Vietnamese government quickly formed the national steering committee to control Covid-19. Thermal inspection and health 
checkpoints were established at all immigration ports, air, sea and land borders. They conducted extra monitoring for international flights from Wuhan and other provinces with the epicentre of the disease. The Prime Minister of Vietnam encouraged its citizens to practise personal hygiene and wear masks in public; health promotion activities also informed people about the science news of the development of Covid-19 throughout the globe (Quach \& Thi, 2020). Then, Vietnam decided not to issue tourist visas for the three regional passports. Then it began to close the 1,300-kilometer border with its biggest trading partner (China) on the same day and postponed the opening of schools after the Chinese New Year.

In Indonesia, there was the surprising fact that there was no case detected until the end of February in 2020. Various assumptions developed regarding endurance, air temperature to the actual statement, showing optimism in facing pandemics. At certain moments, government officials delivered convincing arguments where Covid-19 would not be detected in Indonesia. The World Health Organization (WHO) Director General, Tedros Adhanom Ghebreyesus, urged President Joko Widodo to improve the state's emergency response mechanism in decreasing the Covid-19 outbreak, among other actions, declaring a national emergency. Tedros went on to say that the country must intensify case finding, contact tracing, surveillance, contact quarantine and case isolation (The Jakarta Post, 2020). The confidence about Indonesia being free from a pandemic could not be maintained after cases were confirmed on March 2, 2020, and showed an increasing trend in cases. Until May 31, 2020, it reached 25,773 positive confirmed cases, 7,015 recovered, 1,573 people died, or $6.1 \%$, above the Asian regional average of $2.9 \%$ died (Kemenkes RI, 2020).

\section{Countermeasures of Covid-19: Vietnam and Indonesia in Comparison \\ Vietnam}

After the virus was detected in January 2020 in Vietnam, the central government handled the disease responsively, supported by various governmental bodies. Looking at the political will character, the politicians intend to prevent the virus from spreading when the disease has not been detected in this country by issuing some crucial decisions. The character of policymaking leads to being centralist, forcing people to comply with various disease prevention policies. The government decided on a series of guidelines and precautions, including mandatory health declarations, additional symptom checks and SARS Cov-2

Figure 1.

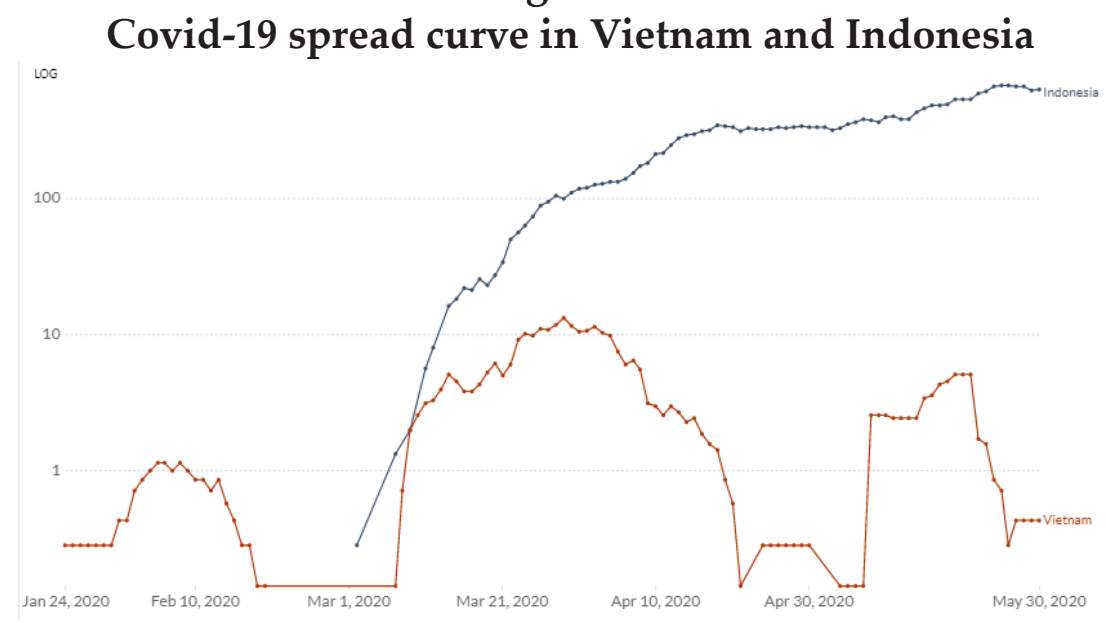

Source: Global Change Data Lab, 2020 
testing for all incoming passengers. Intensive contact tracing is implemented at every level of the government health system, including the Ministry of Health, Ministry of Technology and Science, Ministry of Public Security, local Centres for Disease Control, and local authorities. The test range was 2.68 thousand people, with a total of 261,004 (as of April 29, 2020) (Global Change Data Lab, 2020). In 2017, Vietnam had a ratio of 0.8 doctors per 1,000 population, or eight doctors to serve 10,000 patients (Kompas, 2020). As of March 21, compulsory SARS-CoV-2 testing and 14 days quarantine is required for all international passengers. A comprehensive travel ban for all international flights was released one week later to limit follow-up cases (Than et al., 2021).

The Vietnamese government mobilised participation from its entire political system to fight the COVID-19 epidemic and has achieved some initial successes. Under the direction of the Communist Party of Vietnam (CPV) and the Government of Vietnam, the grassroots health system, including district health centres (707 districts), commune health stations $(10,614$ communes), and networks of health collaborators, has implemented several proactive and comprehensive community health actions against the epidemic (Minh, 2021). Vietnamese government policies during the pandemic were aided by communist party propaganda, which obliged the public to have a vision in combating Covid-19, one of which was the promotion slogan of the war against Covid-19 (Jones, 2020). The motto through the CPV succeeded in creating community obedience. This obedience is internalisation; the obedience is based on intrinsic values or mindset needs; it can be assumed that the Vietnamese people are obedient because the regulations made by the government are their basic needs.

Regarding the leadership style in Vietnam, although Vietnam was not one of the countries with the highest number of cases confirmed, the outbreak was considered complex and unpredictable. The country has strong leadership in formulating strategies and action plans to respond to the disease, as shown by the deputy prime minister by directed and deployed and control measures rapidly from the early phase and following all national spreading. When two people were infected through local transmission, the prime minister quickly promulgated the first directive as an effective preventive measure. Schools have been closed, conferences, festivals, and activities for large crowds have been cancelled, and authorities have encouraged people to stay home to minimise exposure and transmission. Furthermore, the prime minister immediately established the National Steering Committee (NSC) led by Deputy Prime Minister Vu Duc Dam. The committee is a multi-ministerial and cross-sector institution, launched on January 30,2020 , to cover all areas and approach viruses at the local level in 63 provinces and 707 districts (Alam, 2020; Nguyen \& Vu, 2020; Than et al., 2021).

The strength of the bureaucratic government is to treat the disease controlled by the CPV through the National Assembly tasked with implementing government regulations in dealing with the pandemic. A solid apparatus is reflected in all ministries and institutions at the local level in implementing priority programs from the prime minister. Furthermore, the Vietnamese Health Ministry collaborates with The U.S. Centres for Disease Control and Prevention (CDC) to develop guidelines for Covid-19 surveillance, laboratory testing, and infection prevention and control (IPC). The speed of the Ministry of Health in Vietnam in compiling Standard Operating Procedures (SOP) led to the acceleration of the response to Covid-19. The key to success in this SOP included quickly implementing laboratory testing, field investigations, surveillance, and data analysis through solid support from the CDC (CDC, 2020). Vietnam's Ministry of Health also collaborates with Vietnam's Ministry of 
Information and Communications and the Vietnam Ministry of Transport. Through this cross-ministerial collaboration, a responsive prevention policy is produced, namely a health propaganda policy and a policy on the closure of cross-border access and restrictions and supervision of local transportation between provinces.

At the beginning of the pandemic, the Vietnamese government had issued a blunder policy: the Vietnam National Administration of Tourism promoted a campaign called "Vietnam-Safe Haven", while the spread of Covid-19 was still at an early stage. Then, with the closure of schools, parents and students decided to take a vacation, which caused further infections. On the other hand, the Ministry of Education and Training failed to provide timely educational guidelines. Despite this error, all confirmed cases were discharged from the hospital; Deputy Prime Minister Vu Duc Dam has declared that Vietnam "won the first battle against the epidemic" (La et al., 2020). The Vietnamese government has made a program to fulfil people's food needs by distributing free food, such as meat and vegetables (Basoni, 2020). Propaganda and fulfilling food needs have implications for the beliefs and positive attitudes of the people of Vietnam to fight the plague; they obeyed all government policies during the pandemic. Community obedience with government policies was able to suppress the virus spreading so that Vietnam is included in the category of countries that successfully beat Covid-19 (Bar-Yam, 2020).

\section{Indonesia}

In general, the central government of Indonesia has struggled to make decisions quickly, coherent and effective policies to alleviate the health crisis after some cases were detected. However, at the beginning of the pandemic, the president initially ignored the threat, and when it did react, the crisis policies were piecemeal and confusing. In March, the
WHO requested Indonesia to respond more severely to the disease, while Jakarta's foreign diplomats openly criticised the executive's lacklustre campaign. Then, the Indonesian government decided to form a new ad-hoc called the Covid-19 task force headed by the Head of the National Disaster Management Authority. The response to Covid-19 directed by the task force did not perform optimally (Mietzner, 2020).

In handling the deadly virus, the task force has faced complex problems: low health governance, lack of human resources, limited disaster management funds, and limited hospital infrastructure. It can be seen that the testing coverage was low, only 0.2 tests per thousand people for a total of 216,769 (until May 30 2020). Furthermore, the ratio of doctors in Indonesia is 0.4 doctors per 1,000 populations, thus the availability of four doctors serving 10,000 patients. The high disparity follows this condition in the availability of doctors between affected areas, especially lung specialists, anaesthesia specialists, and specialist pulmonary consultant children (Global Change Data Lab, 2020; Kompas, 2020).

In regard to leadership style, Indonesia is a democratic country with a decentralised system (regional autonomy) where each province can govern its territorial problems. Unfortunately, the handling of the pandemic in a country that adheres to democracy is hampered by a leadership style that tends to be anti-democratic, where they ignore medical advice and criticism of the community. The leaders who had promoted themselves as strong decision-makers turned out to be policy amateurs who did not understand the medical system. Consequently, the damaged democratic system was less prepared for the Covid-19 outbreak (Mietzner, 2020). In addition, the central government is not sufficient in enforcing the implementation of policies in all regions.

The decision-making process faces horizontal and vertical debates that have 
confused. The president's policies, ministerial level, task force, and local government are inconsistent and contradictory. This condition is exacerbated by inconsistent policies such as the emergence of a discourse on civil emergency, relaxation of large-scale social restrictions to the new normal (literally, Normal Baru) discourse, while the curve of confirmed cases has not yet sloped. Inconsistency in application raises various assumptions from the community; besides, it causes non-compliance in some circles of society, which is indicated by the mobility from the red zone to various areas and crowds in various places that do not meet health protocols. In conducting programs, the central government encountered obstacles in unifying interests across ministries and state institutions due to the unclear role of each institution in handling Covid-19. On the other hand, implementing government policies in handling Covid-19 is constrained by bureaucratic behaviour more concerned with administration than field conditions. For example, social assistance was hampered due to administrative errors between the Ministry of Social Affairs and the Ministry of Villages in collecting data on beneficiaries.

The Indonesian government adopted a response that used elements of what other countries had successfully attempted. For instance, the ruler implements social distancing policies and large-scale social restrictions, working from home, also studying at home. The Indonesian government provides a threat of sanctions, but it does not affect the psychology of the community to be obedient to policies and fails to create obedience. People are more concerned with the economic business rather than fear legal sanctions from the government. Many local leaders are calling for stricter measures, but Jokowi refused to heed their advice because he prioritised the preservation of the economy. Then, the government provides economic assistance packages, including the Indonesian
Conditional Cash Transfer Programme, Non-Cash Food Assistance, and Direct Cash Assistance from the Village Fund (Hartanto, 2020; Mietzner, 2020). The economic assistance package is expected to create the obedience to implement all government regulations during the Covid-19 pandemic.

The obedience does not last long because the central government makes inconsistent policies such as those that allow crowds in traditional markets (Sari, 2020), the operation of all modes of transportation on May 7, citizens with special needs may travel during the prohibited home returning period, for people to travel if parents are sick or married. These inconsistent government policies were followed by low community obedience to health protocol rules (Gunadha \& Nabilla, 2020). The central government has the intention to create internalisation obedience through public awareness efforts, for instance, public socialisation, in order, the public can follow health protocol rules by understanding that government policies are made for the benefit and safety of the community.

This internalisation effort is also still low due to the government's inconsistency to provide appropriate examples to the community, such as the government's statement to make peace with Covid-19 and implement a new normal (Ihsanuddin, 2020). This condition directly gives a sense of neglecting that causes the community to lose the fundamental values of internalisation, which is its intrinsic value. Anomalous government policies prove to be lousy coordination between the central and regional governments (Ernis, 2020). Government inconsistencies and low public obedience impact the spread of Covid-19 that has not been controlled; currently, Indonesia is included in the countries that require action (Bar-Yam, 2020). Prevention of pandemic spreading is done through various political decision packages that are reactive, not preventive steps. Important centralist decisions 
began to be implemented after various cases showed significant developments. Handling in the regions is dealt with central policies and budgets; for example, the quarantine decision of the Tegal City and Papua areas is hindered by the central policy, which implements largescale social distance. On the other hand, not all regions have strong financial capacities; one thing that is not affordable by the central government is the mitigation of a pandemic in the area while decision making depends on the central government.

\section{Discussion}

The rapid spread of Covid-19 requires public officials (politicians) to respond to the people's needs by making appropriate and fast decisions. The outbreak has challenged the governance and government capacity in tackling the disease in the pre-disaster and post-disease stages. The Covid-19 outbreak early warning system in China failed, which the government system dominated by bureaucratic forces will be most likely to fail. The lack of autonomy of the scientific/professional community from virologists, doctors, and epidemiologists is one of the main contributing factors to the failure of the early warning system. In addition, the key elements in overcoming the cases are fast responses, including effective communication, evidencebased solid decision making, reliable and robust surveillance systems and flexible public health responses. To respond to the pandemics effectively, the government can manage simulation exercises that can be considered more to maintain the proper preparedness and response to future pandemics $(\mathrm{Gu} \& \mathrm{Li}, 2020$; Sambala \& Manderson, 2017; Yu, 2020).

In the pre-health disaster, the two countries showed different responses and decisionmaking patterns. The Vietnamese government has calculated the various possible risks that will be faced and taken strategic policies to prevent transmission. The responsiveness is demonstrated by its ability to take protective steps against its citizens from the disease before spreading widely. The prevention of Covid-19 spreading in this country was very fast and reactive; they learned from previous experience handling SARS. The coercion of the people to obey the state's rules supports the broader community; besides, the government has gained strong trust. Meanwhile, in Indonesia, it is clear that the government tends to be slow to respond to potential health hazards despite establishing Covid-19 as a Disease and preparing health protocols and screening arrivals at various international airports.

Political will and leadership style are two elements that reasonably influence disease handling in these two countries. As an authoritarian democracy, Vietnam has shown evidence of a fast response, an essential record for successful disease response. The character of the socialist state influences the pattern of decision-making that prevents them from the horizontal and vertical debate. A centralised system is supported by collaboration with competent institutions as CDC, accompanied by a massive campaign to combat outbreaks controlled by the ruling party. Although there were policy blunders such as tourism promotion and school openings in times of tightened activity, the leaders managed to control and recover quickly. Indonesia, as a democracy, has been hampered by the handling of the pandemic by a leadership style that tends to be anti-democratic where they ignore health experts. The orientation toward regulations is still solid and tends to place rules and procedures (health protocol) as the key in handling Covid-19 cases.

Public responsibility held by the bureaucracy is still low because it uses an approach that tends to place the bureaucracy as a regulator. From this perspective, the public responsibility of the bureaucracy only sees limited conformity between authority and mandate with the formal rules applied. Public 
bureaucracy uses bureaucratic standards of interests, not based on public interest standards or acts utilising an average of values between bureaucracy and citizens (Silalahi \& Syafri, 2015). Vietnam has a solid apparatus reflected in all ministries and institutions at the local level in implementing priority programs from the prime minister. Meanwhile, In Indonesia, since the adoption of the large-scale social distance on April 10, 2020, its application in the regions must get permission from the Ministry of Health. The decision making was slow, rigid and centralistic as these results in weak development of creativity and innovation in countermeasures. The character of the bureaucracy that tends to prioritise procedures in large-scale social distance decision-making in Indonesia hinders decision-making and policy implementation.

Both Vietnam and Indonesia have had priority programs in dealing with shocks in the health sector. The agenda in both countries can be seen with rapid tests, social assistance, and economic recovery to encourage accelerated handling and restoration of socio-economic conditions. The strong central government control in Vietnam has implications for regularity in implementing the agenda that has been planned and determined. Even though this country faces various challenges, they can overcome them and the government and build trust in the people. In Indonesia, critical decision-making and implementation of control policies is a contentious challenge at various levels of government. Likewise, with priority programs such as providing social assistance, various problems such as the synchronisation of recipient data hinder assisting.

\section{Conclusion}

This study aimed to analyse the responsiveness in preventing the spread of Covid-19 in Vietnam and Indonesia. Both countries have had different ways of handling the external shock in the health sector in pre- pandemic and pandemic times. The speed in handling indicated the responsiveness of the Vietnamese government in making essential policies to prevent pre-pandemic by collaborating with the CDC. The rulers played a significant role in overcoming the disease when the outbreak spread out; this was affected by the strong political will and leadership style, solid bureaucratic apparatus in implementing policies and priority programs. Although this country made blunder policies by promoting tourism and opening schools when the virus has been spreading, the administrator quickly flattens the transmission of viruses through the essential step.

In contrast, the Indonesian government showed the response to handle the shock by issuing some policies, arranging health protocols and implementing policies or programs, but it was conducted slowly. This policy was implemented after various cases were confirmed in various regions throughout Indonesia so that the spread was not controlled. In addition, this democratic country tends to avoid the health experts' and the community's opinions. The prevention of Covid-19 in both countries shows that government responsiveness is essential in handling a pandemic. A responsive government can reduce the pandemic spread, while a government with weak responsiveness results in uncertain health governance.

This research has contributed to how two countries with relatively weak economic capabilities and health systems handled the pandemic in the pre-pandemic and until the end of May 2020. However, this research has limitations where in the parameters used are only pre-pandemic and during the pandemic by comparing political will, leadership style, bureaucracy style, and program. Based on the results of this discussion, this paper recommends a pattern of controlling infectious outbreaks that use preventive learning steps from Vietnam, not the curative as is currently practised in Indonesia. Preventive actions from politicians 
and bureaucracies are on-demand; it provides health insurance to its citizens by looking at various developments that will occur.

\section{References}

Alam, S. (2020). Vietnam: A success story in fight against COVID-19. Anadolu Agency. https://www.aa.com.tr/en/asia-pacific/ vietnam-a-success-story-in-fight-againstcovid-19/1866670

Ali, F. M. H., Nikoloski, Z., \& Reka, H. (2015). Satisfaction and responsiveness with healthcare services in Qatar-evidence from a survey. Health Policy, 119(11), 1499-1505. https://doi. org/10.1016/j.healthpol.2015.09.012

Bar-Yam, Y. (2020). Some are winning-some are not. New England Complex Systems Institute. https://www.endcoronavirus.org/ countries

Basoni, S. (2020). Pemerintah Vietnam bagikan makanan gratis selama masa karantina virus Corona. Detik. https://food.detik. com/info-kuliner/d-4942152/pemerintahvietnam-bagikan-makanan-gratis-selamamasa-karantina-virus-corona

Bryer, T. A. (2007). Toward a relevant agenda for a responsive public administration. Journal of Public Administration Research and Theory, 17(3), 479-500. https://doi. org/10.1093/jopart/mul010

CDC. (2020). Vietnam responds to COVID-19 with technical support from CDC. CDC. https://www.cdc.gov/globalhealth/stories/ vietnam-covid-response.html

Connolly, J. (2015). The "wicked problems" of governing UK health security disaster prevention: The case of pandemic influenza. Disaster Prevention and Management, 24(3), 369-382. https://doi.org/10.1108/DPM-092014-0196

Cope, G. H. (1997). Bureaucratic reform and issues of political responsiveness. Journal of Public Administration Research and Theory, 7(3), 461-471. https://doi.org/10.1093/ oxfordjournals.jpart.a024359
Corbin, J., \& Strauss, A. (2015). Basic of qualitative research: techniques and procedures for developing grounded theory ( $4^{\text {th }}$ ed.). Sage. https://us.sagepub.com/ en-us/nam/basics-of-qualitative-research/ book235578\#preview

Denhardt, J. V., \& Denhardt, R. B. (2015). New public service: Serving, not stearing ( $4^{\text {th }}$ ed.). Routlegde. https://doi. org/10.4324/9781315709765

Djalante, R., Lassa, J., Setiamarga, D., Sudjatma, A., Indrawan, M., Haryanto, B., Mahfud, C., Sinapoy, M. S., Djalante, S., Rafliana, I., Gunawan, L. A., Surtiari, G. A. K., \& Warsilah, H. (2020). Review and analysis of current responses to COVID-19 in Indonesia: Period of January to March 2020. Progress in Disaster Science, 6, 1-9. https:// doi.org/10.1016/j.pdisas.2020.100091

Ernis, D. (2020). Akrobat tanpa kabar pusat: Koordinasi pemerintah pusat dan daerah mengatasipenyebaran coronaberantakan. Muncul perlawanan dari daerah. Tempo. https://majalah. tempo.co/read/laporan-utama/159951/ berantakannya-koordinasi-pemerintahpusat-dan-daerah-menanggulangi-corona

Global Change Data Lab. (2020). Statistic and Research Coronavirus Pandemic (COVID-19). https://ourworldindata.org/covid-testing

Gonzi, R. D. (2019). Public sector responses to radical change: An analysis of theoretical models. In Change and continuity management in the public sector: The DALI model for effective decision-making (pp.31-69). Emerald Publishing Limited. https://doi. org/10.1108/978-1-78973-167-520191002

Gu, E., \& Li, L. (2020). Crippled community governance and suppressed scientific/ professional communities: a critical assessment of failed early warning for the COVID-19 outbreak in China. Journal of Chinese Governance, 1-18. https://doi.org/1 0.1080/23812346.2020.1740468

Gunadha, R., \& Nabilla, F. (2020). 4 kebijakan transportasi dan aturan mudik yang diubah 
Menhub. Suara. https://www.suara.com/ news/2020/05/06/143220/4-kebijakantransportasi-dan-aturan-mudik-yangdiubah-menhub

Harari, Y. N. (2018). Homo Deus: Masa depan umat manusia. Alvabet.

Hartanto, A. D. (2020, May 13). Siasat Daerah Kelola Bantuan Sosial Selama Pandemi Covid. Tirto. https://tirto.id/siasat-daerahkelola-bantuan-sosial-selama-pandemicovid-fsc3

Hou, C., Chen, J., Zhou, Y., Hua, L., Yuan, J., He, S., Guo, Y., Zhang, S., Jia, Q., Zhao, C., Zhang, J., Xu, G., \& Jia, E. (2019). The effectiveness of the quarantine of Wuhan city against the Corona Virus Disease 2019 (COVID-19): well-mixed SEIR model analysis. 0-3. https://doi.org/10.1002/jmv.25827

Ihsanuddin. (2020). Jokowi sebut hidup berdamai dengan Covid-19, apa maksudnya? Kompas. https://nasional.kompas.com/ $\mathrm{read} / 2020 / 05 / 08 / 06563101 /$ jokowi-sebuthidup-berdamai-dengan-covid-19-apamaksudnya

JHU. (2020). COVID-19 dashboard by the center for Systems Science and Engineering (CSSE). https://www.arcgis.com/ apps/opsdashboard/index.html\#/ bda7594740fd40299423467b48e9ecf6

Ji, T., Chen, H., Xu, J., Wu, L., Li, J., Chen, K., \& Qin, G. (2020). Lockdown contained the spread of 2019 novel coronavirus disease in Huangshi city, China: Early epidemiological findings. Clinical Infectious Diseases. https://doi.org/https:// doi.org/10.1093/cid/ciaa390

Jones, A. (2020). Coronavirus: How "overreaction" made Vietnam a virus success. BBC News. https://www.bbc.com/news/worldasia-52628283

Kemenkes RI. (2020). Situasi terkini perkembangan Coronavirus Disease (COVID-19) 31 Mei 2020. Kemenkes RI. https://infeksiemerging. kemkes.go.id/
Kompas. (2020, April 21). Pandemi Covid-19: Tenaga kesehatan di ambang kritis. Kompas, $1+15$.

La, V. P., Pham, T. H., Ho, M.-T., Nguyen, M.H., Nguyen, K.-L. P., Vuong, T.-T., Nguyen, H. K. T., Tran, T., Khuc, Q., Ho, M.-T., \& Vuong, Q.-H. (2020). Policy response, social media and science journalism for the sustainability of the public health system amid the COVID-19 outbreak: The Vietnam lessons. Sustainability, 12(2931), 1-27. https://doi.org/10.3390/su12072931

Lau, H., Khosrawipour, V., Kocbach, P., Mikolajczyk, A., Ichii, H., Schubert, J., Bania, J., \& Khosrawipour, T. (2020). Internationally lost COVID-19 cases. Journal of Microbiology, Immunology and Infection. https://doi.org/10.1016/j.jmii.2020.03.013

Leedy, P. d., \& Ormrod, J. E. (2016). Practical Research Planning and design ( $7^{\text {th }}$ ed.). Pearson Education Limited. https://pce-fet.com/common/library/ books/51/2590_\%5BPaul_D._Leedy,_ Jeanne_Ellis_Ormrod\%5D_Practical_Res(bok.org).pdf

Lin, Q., Zhao, S., Gao, D., Lou, Y., Yang, S., Musa, S. S., Wang, M. H., Cai, Y., Wang, W., Yang, L., \& He, D. (2020). A conceptual model for the coronavirus disease 2019 (COVID-19) outbreak in Wuhan, China with individual reaction and governmental action. International Journal of Infectious Diseases, 93, 211-216. https://doi. org/10.1016/j.ijid.2020.02.058

Mietzner, M. (2020). Populist Anti-Scientism, Religious Polarisation, and Institutionalised Corruption: How Indonesia's Democratic Decline Shaped Its COVID-19 Response. Journal of Current Southeast Asian Affairs, 39(2), 227-249. https://doi. org/10.1177/1868103420935561

Minh, H. Van. (2021). Proactive and Comprehensive Community Health Actions to Fight the COVID-19 Epidemic: Initial 
Lessons from Vietnam. Journal of Rural Health, 37(1), 148. https://doi.org/10.1111/ jrh.12430

Nguyen, T. H. D., \& Vu, D. C. (2020). Summary of the COVID-19 outbreak in VietnamLessons and suggestions. Travel Medicine and Infectious Disease. https://doi.org/10.1016/j. tmaid.2020.101651

Quach, H.-L., \& Thi, N.-A. H. (2020). COVID-19 in Vietnam: A lesson of pre-preparation. Journal of Clinical Virology. https://doi. org/10.1016/j.jcv.2020.104379

Saltzstein, G. H. (1992). Bureaucratic Responsiveness: Conceptual Issues and Current Research. Journal of Public Administration Research and Theory, 2(1), 6388. https://doi.org/10.1093/oxfordjournals. jpart.a037112

Sambala, E. Z., \& Manderson, L. (2017). Anticipation and response: pandemic influenza in Malawi, 2009. Global Health Action, 10(1), 1-13. https://doi.org/10.1080 /16549716.2017.1341225

Sari, H. P. (2020). Jokowi tak masalah pasar kembali ramai, Komisi VIII: Itu langgar PSBB. Kompas. https://nasional.kompas.com/ $\mathrm{read} / 2020 / 05 / 19 / 14331701 /$ jokowi-takmasalah-pasar-kembali-ramai-komisi-viiiitu-langgar-psbb

Silalahi, U., \& Syafri, W. (2015). Desentralisasi dan demokrasi pelayanan publik: Menuju pelayanan pemerintah daerah lebih transparan, partisipatif, responsif dan akuntabel. IPDN Press. http://eprints.ipdn.ac.id/2490/1/ Desentralisasi\%20Demokratis.pdf

Sugiyono. (2014). Metode Penelitian Kombinasi (mixed Methods). In Alfabeta (VI).

Sukmana, M., Aminuddin, M., \& Nopriyanto, D. (2020). Indonesian government response In COVID-19 Disaster Prevention. East African Scholars Journal of Medical Sciences, 3(3), 81-86. https://doi.org/10.36349/ EASMS.2020.v03i03.025
Than, H. M., Nong, V. M., Nguyen, C. T., Thi Tran, N. H., Do, C. D., \& Pham, T. N. (2021). Management of mild cases of COVID-19 in low-resource countries: An experience in Vietnam. Journal of Microbiology, Immunology and Infection, 54(1), 139-140. https://doi. org/10.1016/j.jmii.2020.04.012

Thanh, H. N., Van, T. N., Thu, H. N. T., Van, B. N., Thanh, B. D., Thu, H. P. T., Kieu, A. N. T., Viet, N. N., Marks, G. B., Fox, G. J., \& Nguyen, T. A. (2020). Outbreak investigation for COVID-19 in northern Vietnam. The Lancet Infectious Diseases, 20(5), 535-536. https://doi.org/10.1016/S14733099(20)30159-6

The Jakarta Post. (2020, March 14). COVID-19: WHO urges Jokowi to declare national emergency. The Jakarta Post. https://www. thejakartapost.com/news/2020/03/14/covid19-who-urges-jokowi-to-declare-nationalemergency.html

Valentine, N., Verdes-Tennant, E., \& Bonsel, G. (2015). Health systems' responsiveness and reporting behaviour: Multilevel analysis of the influence of individual-level factors in 64 countries. Social Science and Medicine, 138, 152-160. https://doi.org/10.1016/j. socscimed.2015.04.022

WHO. (2020). Coronavirus disease COVID-2019 Situation Report-131. World Health Organization. https://www.who.int/docs/ default-source/coronaviruse/situationreports/20200530-covid-19-sitrep-131. pdf?sfvrsn=d31ba4b3_2

Yang, K., \& Pandey, S. K. (2007). Public responsiveness of government organisations: Testing a preliminary model. Public Performance \& Management Review, 31(2), 215-240. https://doi.org/10.2753/ PMR1530-9576310204

$\mathrm{Yu}, \mathrm{J}$. (2020). Confronting and governing the public health emergency. Journal of Chinese Governance. https://doi.org/10.1080/238123 46.2020.1744260 